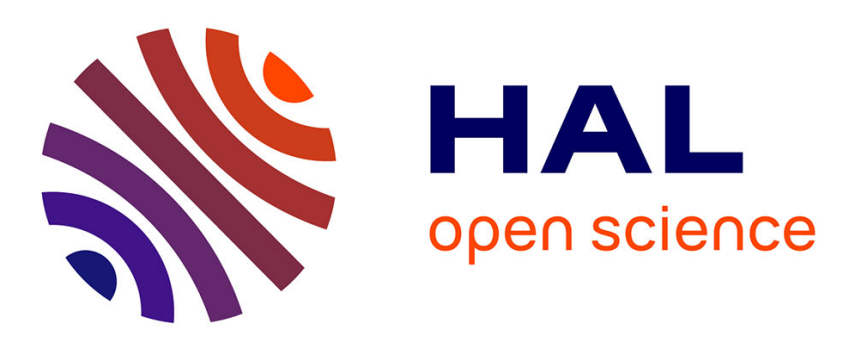

\title{
Determination of aqueous inclusion complexation constants and stoichiometry of alkyl(methyl)-methylimidazolium-based ionic liquid cations and neutral cyclodextrins by affinity capillary electrophoresis
}

Yannis Francois, Anne Varenne, Juliette Sirieix-Plenet, Pierre Gareil

\section{To cite this version:}

Yannis Francois, Anne Varenne, Juliette Sirieix-Plenet, Pierre Gareil. Determination of aqueous inclusion complexation constants and stoichiometry of alkyl(methyl)-methylimidazolium-based ionic liquid cations and neutral cyclodextrins by affinity capillary electrophoresis. Journal of Separation Science, 2007, 30 (5), pp.751-760. 10.1002/jssc.200600386 . hal-02440088

\author{
HAL Id: hal-02440088 \\ https://hal.science/hal-02440088
}

Submitted on 14 Jan 2020

HAL is a multi-disciplinary open access archive for the deposit and dissemination of scientific research documents, whether they are published or not. The documents may come from teaching and research institutions in France or abroad, or from public or private research centers.
L'archive ouverte pluridisciplinaire HAL, est destinée au dépôt et à la diffusion de documents scientifiques de niveau recherche, publiés ou non, émanant des établissements d'enseignement et de recherche français ou étrangers, des laboratoires publics ou privés. 


\title{
DETERMINATION OF AQUEOUS INCLUSION COMPLEXATION CONSTANTS AND STOICHIOMETRY OF ALKYL(METHYL)METHYLIMIDAZOLIUM-BASED IONIC LIQUID CATIONS AND NEUTRAL CYCLODEXTRINS BY AFFINITY CAPILLARY ELECTROPHORESIS
}

\author{
Yannis François, Anne Varenne, Juliette Sirieix-Plenet, Pierre Gareil*
}

Laboratory of Electrochemistry and Analytical Chemistry, UMR 7575 CNRS-ENSCPUPMC, ENSCP, 11 rue Pierre et Marie Curie, 75231 Paris cedex 05, France

Running title: Inclusion parameters of ILs imidazolium cations in cyclodextrins by CE

Keywords: affinity capillary electrophoresis, imidazolium based ionic liquids, inclusion constant, neutral cyclodextrins and stoichiometry

* To whom correspondence should be addressed.

E-mail: pierre-gareil@enscp.fr. Tel : 331554263 71. Fax : 33144276750 


\begin{abstract}
An affinity capillary electrophoresis method was developed to characterize the complex formation between seven alkyl(methyl)methylimidazolium based ionic liquid (IL) cations and eight neutral cyclodextrins (CD). The effective mobility data of the IL cations were processed according to classical non-linear and linear treatments to obtain the complex stoichiometry and formation constant $\mathrm{K}$. The majority of systems followed a 1:1 complexation stoichiometry model but in four cases a 1:2 stoichiometry was better satisfied. The $\mathrm{K}$ values obtained for each IL were compared to elucidate the main influences of IL and CD nature. The availability of these data should lend support to various application areas, including the screening and tailoring of new interactions in solution for CE.
\end{abstract}




\section{Introduction}

A great interest is being drawn towards ionic liquids (IL) as alternatives for conventional molecular solvents used in organic synthesis and catalytic reactions [1]. They supplement the family of "green solvents" including water and supercritical fluids. Among these, room temperature ionic liquids are defined as materials containing only ionic species and having a melting point lower than $298 \mathrm{~K}$. They exhibit many interesting properties such as negligible vapor pressure, low melting point, large liquid range, unique solvation ability and overall, the versatility of their physico-chemical properties makes them really attractive. Most of the ILs studied are based on N,N'-dialkylimidazolium cations. They have been recently proposed as solvents in chemical reactions [2-4], multiphase bioprocess operations [5] and liquid-liquid separations [6,7,8], electrolytes for batteries and fuel cells [9], stationary phases in gas chromatography [10-13], mobile phase additives in liquid chromatography [1416] and electrolyte additives in capillary electrophoresis (CE) [17-26].

Due to their ability to form host-guest inclusion complexes with small molecules, natural and derivatized cyclodextrins (CDs) have been widely used as solubilizing, masking, protecting agents of guest molecules of interest in several application areas including pharmaceutical, health care, fragrance, and as reagent in a number of analytical methods. The interest of solubilizing CDs as additive in ILs has been also early recognized and a few data are already available $[11,27,28]$. To lend support to the development of IL-based processes and better evaluate the actual benefit that can be obtained from adding CDs, the knowledge of CD-IL interactions is of prime importance. Such data, however, remain scarce. For instance, in the context of the separation of anthraquinones by CE using dialkylimidazolium-based IL and $\beta-\mathrm{CD}$ as additives to BGE, Qi et al. [24] suggested the presence of an interaction between analyte and IL cation and between analyte and $\beta-\mathrm{CD}$, without contemplating the possibility of an interaction between IL cation and $\beta-\mathrm{CD}$.

Among the different methods available for studying inclusion interactions, mobility shift affinity capillary electrophoresis (ACE), based on the alteration of analyte effective mobility due to in-situ complexation in ligand-containing electrolytes, offers powerful attributes, making it very attractive and well adapted to this task [29-31]. It allows on-line detection and keeps the consumption of analytes and CDs to a minimum. Other advantages are the short analysis times, the absence of solid phase, high versatility and the possibility to customize experimental conditions to meet specific needs. Linear, such as Scatchard plot [32, 
33] or non-linear [34] regression analysis of the mobility data as a function of ligand concentration allow to derive the inclusion constant and check stoichiometry

This work promotes ACE for the quantitative characterization of complexes between a series of imidazolium-based IL cations and neutral CDs in water. This approach should be of interest for various applications, especially in the fields of liquid chromatography and CE. To generate a broad range of data, seven ILs, differing in the length of the alkyl chain $\left(\mathrm{C}_{4}-\mathrm{C}_{12}\right)$ at the $\mathrm{N} 1$ position of the imidazolium ring, the presence (or not) of a methyl group at the $\mathrm{C} 2$ position of the imidazolium ring and the nature of the IL anion and eight neutral CDs, differing in size and shape of the cavity and external groups close to its rim, were selected.

\section{Theoretical}

ACE in its mobility shift format has been widely used to study analyte-ligand interactions. This method is a variant of zonal electrophoresis consisting in the injection of a small amount of the analyte of interest while the ligand is present in the running buffer. Provided that the analyte and the ligand have fast association-dissociation kinetics and that the absolute mobilities of the free and bound forms of the analyte are different, then a shift in the position of the analyte peak is expected as the ligand concentration in the running buffer varies.

The general ACE approach quantitatively exploits the changes in electrophoretic mobilities of an analyte due to complex formation upon addition of increasing amounts of a ligand to a separation electrolyte. Detailed theoretical treatments and discussions on experimental methods and considerations on the estimation of binding constants can be found in literature [35-37]. Basically, these methods were adapted from similar chromatographic procedures. A molecular association between an analyte and a ligand can be described by the general rectangular hyperbolic form of a binding isotherm:

$$
y=\frac{a x}{b+c x}
$$

The dependent variable, $\mathrm{y}$, is the experimentally measured response of the analyteligand system (in the present case, the effective electrophoretic mobility) while the free variable $\mathrm{x}$ is the concentration of free ligand. $\mathrm{a}, \mathrm{b}$ and $\mathrm{c}$ are constants related to the properties 
of the analyte, ligand and complex, and including the complexation constant and stoichiometry information.

\section{Case of 1:1 complexation equilibrium}

A 1:1 complexation equilibrium model was selected $a b$ initio to describe the IL cation-CD complex. The complexation equilibrium can then be simply schematized as:

$$
\text { IL cation (C) + Ligand (L) } \rightleftarrows \text { Complex } 1 \text { (CL) }
$$

The apparent formation constant relative to this equilibrium is:

$$
K_{1}=\frac{[C L]}{[C][L]}
$$

where $[C L],[C]$ and $[L]$ are the concentrations of complex 1, free IL cation and free ligand, respectively.

When a free IL cation is injected in a separation electrolyte containing the ligand, the resulting effective mobility ( $\mu_{C}{ }^{\text {eff }}$ ) of the IL cation in equilibrium with the ligand is the average of the actual mobilities of the free $\left(\mu_{\mathrm{C}}{ }^{\circ}\right)$ and complexed $\left(\mu_{\mathrm{CL}}{ }^{\circ}\right)$ forms of the IL cation, weighted by the molar fractions :

$$
\mu_{C}^{e f f}=\frac{[C]}{[C L]+[C]} \mu_{C}^{0}+\frac{[C L]}{[C L]+[C]} \mu_{C L}^{0}
$$

which, by introducing Eq. (2), can be rearranged to yield the binding isotherm equation :

$$
v \mu_{C}^{e f f}=\frac{\mu_{C}^{o}+\mu_{C L}^{o} K_{1}[L]}{1+K_{1}[L]}
$$

This equation includes the so-called viscosity correction factor $v$ [38]:

$$
v=\frac{\eta}{\eta^{o}}
$$

where $\eta$ is the viscosity of the running buffer containing a given concentration of ligand $\mathrm{L}$ and $\eta_{0}$ the viscosity the buffer devoid of ligand. Eq. (4) allows for accurate calculations of 
normalized effective mobilities in cases where the viscosity of the running buffer becomes dependent on ligand concentration [37].

Provided that the concentration of the ligand added to the running buffer can be assimilated to the free ligand concentration, Eq. (4) can be either directly handled to obtain complex formation constant by non-linear least-squares fitting [39] or transformed into four linearized forms, classically referred to as the linearized form of the isotherm and its x-reciprocal, $y$ reciprocal and the double reciprocal forms (Table 1) [37]. Although the four linearized equations are equivalent in their algebraic form, the experimental precision on the free and dependent variables will affect the correlation differently, according to whether they are included in the numerator or the denominator of the equation. For example, the impact of the precision on variable [L] will alter when the data are transformed to $1 /[\mathrm{L}]$ for plotting in the $\mathrm{x}$-reciprocal and double reciprocal methods. Thus these plots give more statistical weight to the data collected at the lowest concentrations, where the experimental uncertainty is greater [36]. In addition to the complexation constant, it should be noted that the x-reciprocal, $y$ reciprocal and the double reciprocal methods provide the actual mobility of the complexed IL cation $\mu_{\mathrm{CL}}{ }^{\circ}$ (as far as $\mu_{\mathrm{C}}{ }^{0}$ is easily measured directly), whereas the linearized isotherm method requires the $\mu_{\mathrm{CL}}{ }^{\mathrm{o}}$ value to be directly determined experimentally beforehand. A good estimation of the $\mu_{\mathrm{CL}}{ }^{\mathrm{o}}$ value can be obtained by measuring the limiting effective mobility of the IL cation at high CD concentration.

Finally, the experimental verification of the linearity of these plots will ascertain the concordance with a 1:1 complexation equilibrium. It is worth remembering that, more generally, when the assumption of a 1:1 complexation is not made, a Scatchard plot, which is equivalent to a x-reciprocal plot, can give an indication of the stoichiometry of the complexation.

\section{Case of 1:2 complexation equilibrium}

The case of an analyte taking part in 1:1 and 1:2 step by step complexation equilibria in ACE was envisioned by Bowser et al. [34]. The effective mobility of an IL cation C involved in such equilibria can then be written:

$$
v \mu_{C}^{e f f}=\frac{\mu_{C}^{o}+\mu_{C L}^{o} K_{1}[L]+\mu_{C L_{2}}^{o} K_{1} K_{2}[L]^{2}}{1+K_{1}[L]+K_{1} K_{2}[L]^{2}}
$$


where $\mu_{\mathrm{C}}{ }^{\mathrm{o}}, \mu_{\mathrm{CL}}{ }^{\mathrm{o}}$ and $\mu_{\mathrm{CL} 2}{ }^{\mathrm{o}}$ are the actual electrophoretic mobility of the free, 1:1 complexed and 1:2 complexed forms of the IL cation, respectively, and $\mathrm{K}_{2}$ the step by step formation constant of the 1:2 complex, corresponding to equilibrium:

Complex $1(\mathrm{CL})+$ Ligand $(\mathrm{L}) \quad \rightleftarrows$ Complex $2\left(\mathrm{CL}_{2}\right)$

It can be noted that when only 1:1 complexation takes place, Eq. (6) reduces to Eq. (4).

In order to determine the stoichiometry of IL-CD complexes, these two equations were applied to each system to confirm or cancel the 1:1 equilibrium model described previously.

\section{Materials and Methods}

\subsection{Chemicals and reagents}

1-ethyl-3-methylimidazolium bis(trifluoromethanesulfonyl)imide (EMIM $\left.\mathrm{NTf}_{2}\right)(\geq 99 \%)$ and 1-butyl-3-methylimidazolium bis(trifluoromethanesulfonyl)imide (BMIM NTf $\mathrm{NT}_{2}$ ( $\geq 99 \%$ ) were a gift from Institut Français du Pétrole (Solaize, France). 1-butyl-3-methylimidazolium tetrafluoroborate $\left(\mathrm{BMIM} \mathrm{BF}_{4}\right)(\geq 99 \%)$, 1-butyl-2,3-dimethylimidazolium tetrafluoroborate $\left(\mathrm{BMMIM} \mathrm{BF}_{4}\right)(\geq 99 \%)$, 1-octyl-3-methylimidazolium bromide $\left(\mathrm{C}_{8} \mathrm{MIM} \mathrm{Br}\right)(\geq 99 \%), 1$ decyl-3-methylimidazolium tetrafluoroborate $\left(\mathrm{C}_{10} \mathrm{MIM}_{\mathrm{BF}}\right)(\geq 99 \%)$ and 1-dodecyl-3methylimidazolium tetrafluoroborate $\left(\mathrm{C}_{12} \mathrm{MIM} \mathrm{BF}_{4}\right)(\geq 99 \%)$ were synthesized in our group according to procedures previously reported [40].

$\alpha-\mathrm{CD}, \beta-\mathrm{CD}, \gamma-\mathrm{CD}$, hydroxypropyl- $\alpha-\mathrm{CD}(\mathrm{HP}-\alpha-\mathrm{CD})$, hydroxypropyl- $\beta-\mathrm{CD}(\mathrm{HP}-\beta-\mathrm{CD})$ and hydroxypropyl- $\gamma-\mathrm{CD}(\mathrm{HP}-\gamma-\mathrm{CD})$, all of three with a degree of substitution (DS) of 0.6 were a kind gift from Wacker-Chemie (Munich, Germany). Heptakis-(2,6-di-O-methyl)- $\beta$-CD $(\mathrm{DM}-\beta-\mathrm{CD})(>90 \%)$ and heptakis-(2,3,6-tri-O-methyl)- $\beta-\mathrm{CD}$ (TM- $\beta-\mathrm{CD})(>90 \%)$ were purchased from Sigma-Aldrich (St. Louis, MO, USA). Sodium acetate was from Prolabo (Fontenay-sous-Bois, France). Glacial acetic acid (> 99\%), formamide (> 99\%) and hexadimethrin bromide (Polybrene) were supplied by Aldrich (St. Louis, MO, USA). 


\subsection{Capillary electrophoresis instrumentation and methods}

All experiments were performed with a $\mathrm{HP}^{3 \mathrm{D}} \mathrm{CE}$ (Agilent Technologies, Waldbronn, Germany) capillary electrophoresis systems. This apparatus automatically realized all the steps of the measurement protocols, including capillary conditioning, sample introduction, voltage application and diode array detection, and allows to run unattended method sequences. A CE Chemstation (Agilent Technologies, Waldbronn, Germany) was used for instrument control, data acquisition and data handling. Polymicro bare fused-silica capillaries of $50 \mu \mathrm{m}$ i.d. were obtained from Photonlines (Marly-le-Roi, France). They were used in 35 $\mathrm{cm}$ total length (26.5 $\mathrm{cm}$ to detection). Concerning modified capillaries, dynamically coated procedure with polybrene was realized as described in the literature [41-43]. The background electrolytes (BGE) were made up with acetic acid/sodium acetate at $30 \mathrm{mM}$ ionic strength in water to a $\mathrm{pH}$ of 5.0 , containing each cyclodextrin at various concentrations (zero to $50 \mathrm{mM}$, depending on the CD). Formamide $(0.001 \%(\mathrm{v} / \mathrm{v})$ in the BGE) was used as neutral marker to determine the electroosmotic mobility. The sample solutions were prepared by dissolving each IL at a concentration of ca $2 \mathrm{mM}$ in the aqueous sodium acetate buffer, $\mathrm{pH} 5.0 \mathrm{New}$ capillaries were conditioned by successive flushes with $1 \mathrm{M}$ and $0.1 \mathrm{M} \mathrm{NaOH}$ and then with water under a pressure of $935 \mathrm{mbar}$, for $10 \mathrm{~min}$ each. Before any sample injection, the capillary was first rinsed by successive flushes with water and BGE for 2 min and 3 min, respectively. Samples were introduced hydrodynamically by successively applying the pressure to the sample vial (30 mbar for $3 \mathrm{~s}$, approx., $4 \mathrm{~nL}$ ), BGE vial (30 mbar for $1 \mathrm{~s}$ ) and neutral marker vial (30 mbar for $3 \mathrm{~s}$ ). The temperature in the capillary cartridge was set at 25 ${ }^{\circ} \mathrm{C}$. The voltage applied was $20 \mathrm{kV}$ (positive polarity). The acquisition rate was 10 points / s. Analytes were detected by UV absorbance at 200 and $214 \mathrm{~nm}$, according to cases. Capillaries were rinsed with water and dried by air when not in use.

For the determination of inclusion constant by ACE, samples were electrophoresed in serial BGEs containing increasing concentrations of CDs. Injections were repeated twice to check the precision of the data. Numerical data were processed using OriginPro 7.0 software (OriginLab Corporation, Northampton, USA) and Exel 2003 software (Microsoft Corporation, Redmond, USA)

For viscosity measurements of CD-containing BGEs used to calculate viscosity correction factor $\mathrm{v}$, a short plug (ca $4 \mathrm{~nL})$ of a flow marker, formamide, $0.03 \mathrm{v} / \mathrm{v} \%\left(3.10^{-5}\right.$ mol. $\mathrm{L}^{-1}$ ) in the BGE, was first injected under a pressure of $30 \mathrm{mbar}$ for $3 \mathrm{~s}$ in the BGE-filled capillary. The marker zone was next displaced by pushing the BGE under 50 mbar until the 
marker was detected. The measurement of the detection time of the marker, $t_{d}$, was used to calculate viscosity according to Hagen-Poiseuille law:

$$
\eta=\frac{d_{c}^{2} \Delta P t_{d}}{32 l L}
$$

where $\mathrm{d}_{\mathrm{c}}$ stands for the inner diameter of the capillary, $\Delta \mathrm{P}$ for the pressure applied, $\mathrm{L}$ and 1 for the total capillary length and length to detection window, respectively. The calibration of both the pressure delivery system and inner diameter of the capillary $\left(\mathrm{d}_{\mathrm{c}}{ }^{2} . \Delta \mathrm{P}\right.$ term) was realized with solutions of ethyleneglycol $\left(\eta=16.1 \times 10^{-3}\right.$ Pa.s at $\left.25^{\circ} \mathrm{C}\right)$ and diethyleneglycol $(\eta=$ $29.0 \times 10^{-3}$ Pa.s at $25^{\circ} \mathrm{C}$ ).

\section{Discussion}

\subsection{General experimental setup}

The purpose of this work was to develop an ACE method for the determination of the inclusion parameters between imidazolium cations (Figure 1) and different CDs and to provide data of relevance for imidazolium-based ILs. Mobility measurements were performed in a bare fused silica capillary filled with a pH 5.0 acetate buffer of $30 \mathrm{mM}$ ionic strength, keeping Joule heating within the dissipating capacity of the thermoregulation device. The experiments were carried out under positive polarity $(20 \mathrm{kV})$, i.e. in co-electroosmotic migration mode. A neutral marker (formamide) was injected in order to determine the effective mobility of the IL cations. A sequential injection protocol of the IL cation and the neutral marker was devised so that the neutral marker, which was injected second, would never be in contact with the IL cation, thus preventing any risk of deleterious interaction between them.

The viscosity measurements of each CD-containing BGEs were realized to calculate viscosity correction factor $v$. The viscosity correction factor for the buffer system used in this work was related specifically to the concentration of each $\mathrm{CD}$ through a third-order polynomial, except for the $\beta-\mathrm{CD}$, for which it can be calculated from a linear regression (Table 2).

According to the complexation stoichiometry, the inclusion constants were determined in this work both by direct non-linear fitting of the binding isotherms and linear fittings of the 
linearized forms (case of a 1:1 stoichiometry), which permitted to evaluate the quality of the experimental measurements, or by non-linear fitting only (case of a 1:2 stoichiometry).

\subsection{Imidazolium-based IL cation complexation by cyclodextrins.}

In order to investigate on the inclusion complexation between imidazolium-based IL cations and CDs, seven methylimidazolium-based ILs differing in their alkyl chain length at the N1 position $\left(C_{2}\right.$ to $\left.C_{12}\right)$, in the presence or the absence of a methyl group at the $C 2$ position (Figure 1) and in their anion nature $\left(\mathrm{Br}^{-}, \mathrm{BF}_{4}^{-}, \mathrm{NTf}_{2}^{-}\right)$were studied in the presence of eight different neutral CDs ( $\alpha, \beta-, \gamma-$, HP- $\alpha-$, HP- $\beta-$, HP- $\gamma-$, DM- $\beta$-and TM- $\beta-C D)$. For each IL and according to the $\mathrm{CD}$ nature, the $\mathrm{CD}$ concentration added in the running buffer was varied over the range $0.1-50 \mathrm{mM}$.

For the sake of example, Figure 2 shows the electropherograms of $\mathrm{C}_{8} \mathrm{MIM}$ cation obtained with a bare silica capillary for various $\alpha-C D$ concentrations added to the running buffer. Upon increasing $\alpha-C D$ concentration, an increase in the migration time of the IL cation was observed, suggesting a decrease in the charge to mass ratio of the analyte. A similar electrophoretic behavior was observed for the other IL cation/CD systems, indicating the formation of a complex between these species. The peak tailing observed in Figure 2 for $\mathrm{C}_{8} \mathrm{MIM}$ cation could be due to electromigration dispersion or also possibly to wall adsorption of IL cation as reported [18] (i.e. under conditions where wall adsorption is very unlikely due to the positive surface charge borne by this capillary). An identical series of experiments performed in a Polybrene modified capillary led, however, to the same $\mathrm{K}$ values as those obtained with bare silica capillary (results not shown), which indicated that wall adsorption, if present, did not influence $\mathrm{K}$ determination with unmodified silica capillary. $\mathrm{C}_{8} \mathrm{MIM}$ cation peaks were then fitted with the Haarhoff Van der Linde function, allowing better estimation of migration time $[44,45]$. As no significant difference was observed for the determination of the inclusion constant by using this treatment or by directly estimating migration time from peak apex, this latter, simple method was employed subsequently.

The effective electrophoretic mobilities of the IL cations, $\mu_{C}{ }^{\text {eff }}$, were systematically calculated as a function of CD concentration. Direct non-linear fitting (Figure 3) to the binding isotherms (Eq. (4) and Eq. (6)) and linear fitting to the four linearized forms derived from Eq. 
(4) were then performed with these sets of mobility data for the determination of the complexation parameters.

Figure 4 shows the linear treatments performed with the experimental data pertaining to the $\mathrm{C}_{8} \mathrm{MIM}$ cation $-\alpha-\mathrm{CD}$ system. The high degree of linear correlation obtained by the four linearization methods testifies to both the pertinency of the 1:1 complexation model and the precision of the experimental measurements. Similar conclusions can be drawn for the majority of studied imidazolium cations and CDs, displaying correlation coefficients in excess of 0.990 for all the linear regression performed, but in four cases (see below) the fittings to these linearized equations failed to produce linear plots. Interestingly, better correlation coefficients were obtained in these cases by non-linear fitting to Eq. (6), corresponding to a 1:2 complexation stoichiometry. Table 3 summarizes the complexation constants obtained by each plotting method for all the studied IL cation - CD systems. It should be emphasized that for 1:1 complexations, close values of formation constants were generally obtained by the various linear and non-linear plotting methods, although in some cases one of them yields a result which was somewhat different from the other ones. As the method yielding this apparently more scattered result was not the same for the different IL cations, we deemed it better to express the results as the average of the values provided by the five methods. Thus, the use of the five plotting methods seemed preferable for a more reliable determination of the complexation constant.

The results given in Table 3 show, for each $\mathrm{CD}$, a pronounced increase of the $\mathrm{K}_{1}$ value in the order: EMIM $<$ BMIM $\sim$ BMMIM $<\mathrm{C}_{8} \mathrm{MIM}<\mathrm{C}_{10} \mathrm{MIM}<\mathrm{C}_{12} \mathrm{MIM}$. This order emphasized the prominent role of the alkyl chain length of the IL cation in the inclusion mechanism. The nil $\mathrm{K}_{1}$ values obtained for EMIM cation with all the CDs demonstrate that there is no inclusion of the imidazolium ring into the cyclodextrin cavity, whatever its size $(\alpha-, \beta-, \gamma-$

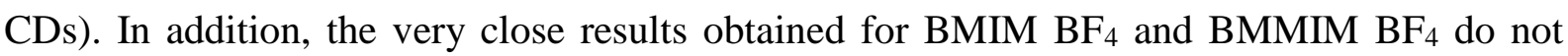
allow to conclude to a significant influence of the presence of a methyl group at the $\mathrm{C} 2$ position. Eventually, the nature and length of the side alkyl chain of the IL cation is by far the major parameter controlling inclusion. These results are in agreement with those by Rekharsky et al. [46], which did not emphasized any complexation phenomenon between imidazolium cation and $\alpha$ - or $\beta$-CD.

As exemplified by studies of BMIM $\mathrm{NTf}_{2}$ and $\mathrm{BMIM} \mathrm{BF}_{4}$ IL samples in the presence of $\alpha-$ $\mathrm{CD}$ and $\mathrm{HP}-\alpha-\mathrm{CD}$, the nature of the anion initially associated to the imidazolium cation in the 
IL sample did not show any significant influence on $\mathrm{K}_{1}$ values obtained. This result can be anticipated insofar as a short plug of dilute IL sample was introduced for the assay and the acetate buffer anion common to all experiments was present in large excess.

The differences in main properties between the three natural CDs and the CD derivatives used in this study, made it difficult to compare $\mathrm{K}_{1}$ values obtained for a given IL cation and different CDs, but these results can be compared according to the CD cavity size for a given type of substituting moiety. For the sake of example, Figure 5 shows a histogram representation of the $\mathrm{K}_{1}$ values for $\mathrm{C}_{8} \mathrm{MIM}$ cation obtained with each $\mathrm{CD}$. For the 1:1 complexation stoichiometry model, a pronounced decrease of the $\mathrm{K}_{1}$ value in the order: $\alpha-C D$ $>\beta-\mathrm{CD}>\gamma-\mathrm{CD}, \mathrm{HP}-\alpha-\mathrm{CD}>\mathrm{HP}-\beta-\mathrm{CD}>\mathrm{HP}-\gamma-\mathrm{CD}$ and DM- $\beta-\mathrm{CD}>\mathrm{TM}-\beta-\mathrm{CD}$ respectively was observed. This order for the natural CD and HP-CD groups emphasized the prominent role of $\mathrm{CD}$ cavity size in the inclusion mechanism. As support by the physical properties recalled in Table 4, which can be considered as approximately valid for HP-CDs [47], $\mathrm{K}_{1}$ values markedly decrease when the cavity diameter increases. Figure 5 also shows a higher $\mathrm{K}_{1}$ value for $\mathrm{C}_{8} \mathrm{MIM}$ with DM- $\beta-\mathrm{CD}$ as compared to TM- $\beta-\mathrm{CD}$. This result was probably due to a more important steric hindrance of TM- $\beta$-CD cavity. Moreover, methylated $\beta$-CDs were known to be more hydrophobic and to have a deeper cavity than $\beta$-CD $[48,49]$. Similar conclusions can be drawn for the majority of studied imidazolium cations and CDs for the 1:1 complexation stoichiometry model.

For the longer alkyl chains at the $\mathrm{N} 1$ position experienced $\left(\mathrm{C}_{10}\right.$ and $\left.\mathrm{C}_{12}\right)$ and in cases concerning complexation by $\alpha-C D$ and $D M-\beta-C D$, much better correlation of the experimental data was obtained with the 1:2 complexation stoichiometry model rather than with the 1:1 model. Such situation, although rare, where two CDs bind a single guest molecule, has already been reported for some molecularly favorable cases [50-52]. Especially, Funasaki et al. recently evidenced 1:2 complexes between long chain surfactant and CDs by NMR studies and proposed a head-to-head position of the CD dimer in the 1:2 complex [5355]. Although the exact interaction mode involved in our ternary systems cannot be ascertained simply from these experiments, it can be inferred that two CD molecules may be threaded likewise along the alkyl side chain, as outlined in Figure 6. 


\section{Conclusion}

An ACE method has been developed for the determination of the inclusion parameters between seven alkyl(methyl)methylimidazolium cations and eight neutral CDs. The majority of systems followed a 1:1 complexation stoichiometry model but in four cases a 1:2 stoichiometry was highlighted. By studying these 56 possible IL/CD systems, it was established that the main factor influencing the strength of the inclusion complexation was the length of alkyl side chain on the imidazolium ring. The presence of a methyl group at the C2 position and the nature of anion associate to the imidazolium cation in the IL did not show significant influence on complexation constant obtained. Also, the size of the CD cavity noticeably impacts the stability of the 1:1 complexes, with stronger complexes being given by $\alpha$-CD. Finally, it was shown that two CD molecules can likely be threaded along $\mathrm{C}_{10}$ and $\mathrm{C}_{12}$ alkyl side chains. The availability of these data should be of support in various application areas, including the screening and tailoring of new interaction in solution for CE. 


\section{References}

[1] Wasserscheidt P., Weldon T., Ionic Liquids in Synthesis, Wiley-VCH, New-York 2003.

[2] Dupont J., de Souza R.F., Suarez P.A.Z., Chem. Rev. 2002, 102, 3667-3692.

[3] Wasserscheidt P., Keim W., Angewandte Chem. Int. Ed. 2000, 39, 3772-3789.

[4] Earle M.J., Seddon K.R., Pure Appl. Chem. 2000, 72, 1391-1398.

[5] Cull S.G., Holbrey J.D., Vargas-Mora V., Seddon K.R., Lye G.J., Biotechnol. Bioeng. 2000, 69, 227-233.

[6] Huddleston J.G., Willauer H.D., Swatloski R.P., Visser A.E., Rogers R.D., Chem. Comm. 1998, 1765-1766.

[7] Fadeev A.G., Meagher M.M., Chem. Comm. 2001, 295-296.

[8] Berthod A., Ruiz-Angel M.J., Huguet S., Anal. Chem. 2005, 77, 4071-4080.

[9] Visser A.E., Swatloski R.P., Rogers R.D., Green Chem. 2000, 2, 1-4.

[10] Pachole F., Butler H.T., Poole C.F., Anal. Chem. 1982, 54, 1938-1941.

[11] Andersen J.L., Ding J., Welton T., Armstrong D.W., J. Am. Chem. Soc. 2002, 124, 14247-14254.

[12] Berthod A., He L., Armstrong D.W., Chromatographia 2001, 53, 63-68.

[13] Heintz A., Kulikov D.W., Verevkin S.P., J. Chem. Eng. Data 2002, 47, 894-899.

[14] He L., Zhang W., Zhao L., Liu X., Jiang S., J. Chromatogr. A 2003, 1007, 39-45.

[15] Kaliszan R., Marszall M.P., Markuszewski M.J., Baczek T., Pernak J., J. Chromatogr. A 2004, 1030, 263-271.

[16] Xiao X., Zhao L., Liu X., Jiang S., Anal. Chim. Acta 2004, 519, 207-211.

[17] Yanes E.G., Gratz S.R., Stalcup A.M., The Analyst 2000, 125, 1919-1923.

[18] Yanes E.G., Gratz S.R., Baldwin M.J., Robinson S.E., Stalcup A.M., Anal. Chem. 2001, $73,3838-3844$.

[19] Vaher M., Koel M., Kaljurand M., Chromatographia 2001, 53, 302-306.

[20] Vaher M., Koel M., Kaljurand M., Electrophoresis 2002, 23, 426-430.

[21] Vaher M., Koel M., Kaljurand M., J. Chromatogr. A 2002, 979, 27-32.

[22] Kuldvee R., Vaher M., Koel M., Kaljurand M., Electrophoresis 2003, 24, 1627-1634.

[23] Vaher M., Koel M., J. Chromatogr. A 2003, 990, 225-230.

[24] Qi S., Cui S., Chen X., Hu Z., J. Chromatogr. A 2004, 1059, 191-198.

[25] Qi S., Li Y., Deng Y., Cheng Y., Chen X., Hu Z., J. Chromatogr. A 2006, 1109, 300306. 
[26] Mwongela S.M., Numan A., Gill N.L., Agbaria R.A., Warner I.M., Anal. Chem. 2003, 75, 6089-6096.

[27] Tran C.D., De Paoli Lacerda S.H., Anal. Chem. 2002, 74, 5337-5341.

[28] Armstrong D.W., He L., Liu Y-S., Anal. Chem. 1999, 71, 3873-3876.

[29] Tanaka Y., Terabe S., J. Chromatogr. B 2002, 768, 81-92.

[30] Rippel G., Corstjens H., Billiet H.A.H., Frank J., Electrophoresis 1997, 18, 2175-2184.

[31] Schou C., Heegaard N.H.H., Electrophoresis 2006, 27, 44-59.

[32] Rundlett K.L., Armstrong D.W., Electrophoresis 1997, 18, 2194-2202.

[33] Rundlett K.L., Armstrong D.W., Electrophoresis 2001, 22, 1419-1427.

[34] Bowser M.T., Chen D.D.Y., Anal. Chem. 1998, 70, 3261-3270.

[35] Connors K.A., Binding Constants. The Measurements of Molecular Complex Stability, John Wiley \& Sons, New York, 1987.

[36] Rundlett K.L., Armstrong D.W., J. Chromatogr. A 1996, 721, 173-186.

[37] Vespalec R., Bocek P., J. Chromatogr. A 2000, 875, 431-445.

[38] Bowser M.T., Sternberg E.D., Chen D.D.Y., Electrophoresis 1997, 18, 82-91.

[39] Bowser M.T., Chen D.D.Y., J. Phys. Chem. A 1999, 103, 197-202.

[40] Cammarata I., Kazarian S.G., Salter P.A., Welton T., Phys. Chem. Chem. Phys. 2001, 3, 5192-5200.

[41] Y.J. Yao, S.F.Y. Li, J. Chromatogr. A 1994, 680, 431-435.

[42] E. Cordova, J. Gao, G.M. Whitesides, Anal. Chem. 1997, 69, 1370-1379.

[43] A. Macia, F. Borrull, M. Calull, C. Aguilar, Electrophoresis 2004, 25, 3441-3449.

[44] Erny G., Bergström E., Goodall D., Grieb S., Anal. Chem. 2001, 73, 4862-4872.

[45] Le Saux T., Varenne A., Gareil P., Electrophoresis 2005, 26, 3094-3104.

[46] Rekharsky M.V., Nemykina E.V., Eliseev A.V., Yatsimirski A.K., Thermochim. Acta 1992, 202, 25-33.

[47] Szejtli J., Pure Appl. Chem. 2004, 76, 1825-1847.

[48] Nishiho J., Shiota S., Mazima K., Inoue Y., Mizuno H., Yoshida J., Chem. Pharm. Bull. 2000, 48, 48-55.

[49] Szejtli J., Cyclodextrin Technology, Kluwer Academic Publisher, Dordrecht, 1988.

[50] Armstrong D.W., Nome F., Spino L.A., Golden T.D., J. Am. Chem. Soc. 1986, 108, 1418-1421.

[51] Connors K.A., Pendergast D.D., J. Am. Chem. Soc. 1984, 106, 7607-7614.

[52] Wan Yunus W.M.Z., Taylor J., Bloor D.M., Hall D.G., Wyn-Jones E., J. Phys. Chem. 1992, 96, 8979-8982. 
[53] Funasaki N., Neya S., Langmuir 2000, 16, 383-388.

[54] Funasaki N., Ishikawa S., Neya S., J. Phys. Chem. B 2004, 108, 9593-9598.

[55] Funasaki N., Ishikawa S., Hirota S., Anal. Chim. Acta 2006, 555, 278-285. 


\section{Captions}

Figure 1: Ionic liquids studied in this work.

1-ethyl-3-methylimidazolium bis(trifluoromethanesulfonyl)imide

$\left(\mathrm{R}=\mathrm{Et}, \mathrm{R}^{\prime}=\mathrm{Me}, \mathrm{R}{ }^{\prime}=\mathrm{H}, \mathrm{A}=\mathrm{NTf}_{2}\right)$

1-butyl-3-methylimidazolium bis(trifluoromethanesulfonyl)imide

$\left(\mathrm{R}=\mathrm{Bu}, \mathrm{R}^{\prime}=\mathrm{Me}, \mathrm{R}{ }^{\prime}=\mathrm{H}, \mathrm{A}=\mathrm{NTf}_{2}\right)$

1-butyl-3-methylimidazolium tetrafluoroborate

$\left(\mathrm{R}=\mathrm{Bu}, \mathrm{R}^{\prime}=\mathrm{Me}, \mathrm{R}{ }^{\prime}=\mathrm{H}, \mathrm{A}=\mathrm{BF}_{4}\right)$

1-butyl-2,3-dimethylimidazolium tetrafluoroborate

$\left(\mathrm{R}=\mathrm{Bu}, \mathrm{R}^{\prime}=\mathrm{Me}, \mathrm{R}{ }^{\prime}\right.$ ' $\left.=\mathrm{Me}, \mathrm{A}=\mathrm{BF}_{4}\right)$

1-octyl-3-methylimidazolium bromide

$\left(\mathrm{R}=\mathrm{C}_{8}, \mathrm{R}^{\prime}=\mathrm{Me}, \mathrm{R}^{\prime}\right.$ ' $\left.=\mathrm{H}, \mathrm{A}=\mathrm{Br}\right)$

1-decyl-3-methylimidazolium tetrafluoroborate

$\left(\mathrm{R}=\mathrm{C}_{10}, \mathrm{R}^{\prime}=\mathrm{Me}, \mathrm{R}^{\prime}{ }^{\prime}=\mathrm{H}, \mathrm{A}=\mathrm{BF}_{4}\right)$

1-dodecyl-3-methylimidazolium tetrafluoroborate

$\left(\mathrm{R}=\mathrm{C}_{12}, \mathrm{R}^{\prime}=\mathrm{Me}, \mathrm{R}^{\prime}=\mathrm{H}, \mathrm{A}=\mathrm{BF}_{4}\right)$

Figure 2: Electropherograms showing the mobility shift of 1-octyl-3-methylimidazolium cation $\left(\mathrm{C}_{8} \mathrm{MIM}\right)$ as a function of $\alpha-\mathrm{CD}$ concentration in the running buffer. A : Zero (neat background buffer) ; B : $1 \mathrm{mM}$; C : $2 \mathrm{mM}$; D : $3 \mathrm{mM}$; E : $5 \mathrm{mM} ; \mathrm{F}: 10 \mathrm{mM}$; G : $20 \mathrm{mM}$; $\mathrm{H}: 30 \mathrm{mM} ; \mathrm{I}: 50 \mathrm{mM}$.

Experimental conditions: bare fused silica capillary, $50 \mu \mathrm{m}$ i.d. x $35 \mathrm{~cm}$ (detection cell, 26.5 $\mathrm{cm}$ ). Running electrolyte: $30 \mathrm{mM}$ sodium acetate buffer, $\mathrm{pH} 5.0$ (ionic strength, $30 \mathrm{mM}$ ) containing $\alpha-\mathrm{CD}$ at various concentrations (A to G). Applied voltage: $20 \mathrm{kV}$ (current intensity: $50 \mu \mathrm{A}$ ). Temperature: $25^{\circ} \mathrm{C}$. Injection protocol: see Experimental. Sample: $2 \mathrm{mM}$ $\mathrm{C}_{8} \mathrm{MIM} \mathrm{Br}$ in the sodium acetate buffer, $\mathrm{pH}$ 5.0. NM: neutral marker.

Figure 3: Variation of the effective mobility $\mu_{\mathrm{C}} \mathrm{eff}^{\mathrm{e}}$ (corrected for viscosity variations) of 1octyl-3-methylimidazolium cation $\left(\mathrm{C}_{8} \mathrm{MIM}\right)$ as a function of the $\alpha-\mathrm{CD}$ concentration in the running electrolyte (binding isotherm plot). The solid line represents the non-linear leastsquares fitting of the data to Eq. 4. Experimental conditions, see Fig. 2.

Figure 4: Linearized representations of the 1:1 binding isotherm for 1-octyl-3methylimidazolium cation $\left(\mathrm{C}_{8} \mathrm{MIM}\right)$, in the presence of variable concentrations of $\alpha-\mathrm{CD}$ : 
directly linearized isotherm (A), x-reciprocal (B), y-reciprocal (C), and double reciprocal (D) forms (see Table 1 for equations). Experimental conditions, see Fig. 2. Concentrations of ligand $\mathrm{L}(\alpha-\mathrm{CD})$ in $\mathrm{M}$ and effective mobilities in $10^{-5} \mathrm{~cm}^{2} \cdot \mathrm{V}^{-1} \cdot \mathrm{s}^{-1}$.

Equations of the least-squares regression straight lines:
$A: y=1184.9 x+0.3542, R^{2}=0.999$
$B: y=-1133.2 x-0.1948, R^{2}=0.994$
$C: y=-5820.1 x-5.3491, R^{2}=0.999$
$D: y=-5.2051 x-5801.2, R^{2}=0.997$

Figure 5 : Histogram representing the $\mathrm{K}_{1}$ value for 1-octyl-3-methylimidazolium cation $\left(\mathrm{C}_{8} \mathrm{MIM}\right)$ as a function of the $\mathrm{CD}$ nature, bars represent standard deviation. Experimental conditions, see Fig. 2.

Figure 6: Schematic representation of (a) the 1:1 and (b) 1:2 complexes between alkyl(methyl)methylimidazolium cation and CDs, as inferred from ref. [55] 
Table 1:

Linearized forms of the binding isotherm recommended for the determination of binding constants using ACE methods in the mobility shift format [33].

\begin{tabular}{|c|c|c|c|}
\hline Method name & Plotting method & $\mathrm{K}$ determination & $\mu_{C L}{ }^{0}-\mu_{C}{ }^{0}$ \\
\hline Isotherm & $\frac{\mu_{C}^{0}-\mu_{C}^{e f f}}{\mu_{C}^{e f f}-\mu_{C L}^{0}}=K[L]=f([L])$ & slope & $\begin{array}{l}\text { To be determined by } \\
\text { experiment directly }\end{array}$ \\
\hline X-reciprocal & $\frac{\mu_{C}^{e f f}-\mu_{C}^{0}}{[L]}=-K\left(\mu_{C}^{e f f}-\mu_{C}^{0}\right)+K\left(\mu_{C L}^{0}-\mu_{C}^{0}\right)=f\left(\mu_{C}^{e f f}-\mu_{C}^{0}\right)$ & - slope & Intercept / slope \\
\hline Y-reciprocal & $\frac{[L]}{\mu_{C}^{e f f}-\mu_{C}^{0}}=-\frac{1}{\mu_{C L}^{0}-\mu_{C}^{0}} \times[L]+\frac{1}{K\left(\mu_{C L}^{0}-\mu_{C}^{0}\right)}=f([L])$ & slope / intercept & 1/slope \\
\hline Double reciprocal & $\frac{1}{\mu_{C}^{e f f}-\mu_{C}^{0}}=-\frac{1}{K\left(\mu_{C L}^{0}-\mu_{C}^{0}\right)} \times \frac{1}{[L]}+\frac{1}{\mu_{C L}^{0}-\mu_{C}^{0}}=f\left(\frac{1}{[L]}\right)$ & intercept / slope & $1 /$ intercept \\
\hline
\end{tabular}


Table 2: Modeling equation of the viscosity correction factor as a function of concentration for each $\mathrm{CD}$ used in this work. Temperature: $25^{\circ} \mathrm{C}$

\begin{tabular}{llc}
\hline Cyclodextrins & \multicolumn{1}{c}{ viscosity correction factor } & $\mathrm{R}^{2}$ \\
\hline$\alpha-C D$ & $v=-453.2842 \times[C D]^{3}+50.48286 \times[C D]^{2}+0.62195 \times[C D]+0.85923$ & 0.999 \\
$\beta-C D$ & $v=2.16459 \times[C D]+0.87687$ & 0.986 \\
$\gamma-C D$ & $v=-170.97535 \times[C D]^{3}+34.66408 \times[C D]^{2}+1.55085 \times[C D]+0.88031$ & 0.999 \\
HP- $\alpha-C D$ & $v=-950.16044 \times[C D]^{3}+86.77135 \times[C D]^{2}+1.25357 \times[C D]+0.8792$ & 0.999 \\
HP- $\beta-C D$ & $v=561.65047 \times[C D]^{3}-27.56666 \times[C D]^{2}+4.42357 \times[C D]+0.87746$ & 0.999 \\
HP- $\gamma-C D$ & $v=728.9039 \times[C D]^{3}-47.25401 \times[C D]^{2}+5.76565 \times[C D]+0.87887$ & 0.999 \\
DM- $\beta-C D$ & $v=1243.28674 \times[C D]^{3}-62.50023 \times[C D]^{2}+4.45666[C D]+0.87708$ & 0.999 \\
TM- $\beta-C D$ & $v=-797.12969 \times[C D]^{3}+101.1041 \times[C D]^{2}+1.1649 \times[C D]+0.87832$ & 0.999 \\
\hline
\end{tabular}




\section{Table 3:}

Step by step inclusion constants $\mathrm{K}_{1}$ and $\mathrm{K}_{2}$ of imidazolium-based IL cations with neutral CDs, as determined by the ACE mobility shift method, using four linearization plotting methods, and a nonlinear fitting method to Eq. (4) and (6). Experimental conditions as in Figure 2. Linearized equations of the $1: 1$ binding isotherm as mentioned in Table 1 


\begin{tabular}{|c|c|c|c|c|c|c|c|}
\hline$\alpha-C D$ & $\begin{array}{c}\mathrm{K}_{1}\left(\mathrm{M}^{-1}\right) \\
\text { equation }(4)\end{array}$ & $\begin{array}{c}\mathrm{K}_{1}\left(\mathrm{M}^{-1}\right) \\
\text { isotherm } \\
\text { method }\end{array}$ & $\begin{array}{c}\mathrm{K}_{1}\left(\mathrm{M}^{-1}\right) \\
\text { x-reciprocal } \\
\text { method }\end{array}$ & $\begin{array}{c}\mathrm{K}_{1}\left(\mathrm{M}^{-1}\right) \\
\mathrm{y} \text {-reciprocal } \\
\text { method }\end{array}$ & $\begin{array}{l}\mathrm{K}_{1}(\mathrm{M}-1) \\
\text { double } \\
\text { reciprocal } \\
\text { method }\end{array}$ & $\begin{array}{c}\text { Average } \\
\text { value for } \mathrm{K}_{1} \\
\left(\mathrm{M}^{-1}\right) \\
\pm \sigma^{*}\end{array}$ & $\begin{array}{c}\mathrm{K}_{1} ; \mathrm{K}_{2} \\
\left(\mathrm{M}^{-1}\right) \\
\text { equation }(6) \\
\pm \sigma^{*} \\
\end{array}$ \\
\hline $\mathrm{EMIM} \mathrm{NTf}_{2}$ & 0 & 0 & 0 & 0 & 0 & 0 & \\
\hline $\mathrm{BMIM} \mathrm{BF}_{4}$ & 29 & 31 & 27 & 26 & 28 & $28 \pm 4$ & \\
\hline BMIM NTf 2 & 32 & 32 & 26 & 26 & 26 & $28 \pm 5$ & \\
\hline $\mathrm{BMMIM} \mathrm{BF}_{4}$ & 33 & 30 & 27 & 28 & 25 & $28 \pm 4$ & \\
\hline $\mathrm{C}_{8} \mathrm{MIM} \mathrm{Br}$ & 1130 & 1185 & 1130 & 1160 & 1115 & $1148 \pm 70$ & \\
\hline $\mathrm{C}_{10} \mathrm{MIM} \mathrm{BF}_{4}$ & & & & & & & $\begin{array}{c}2900 \pm 320 \\
3 \pm 2\end{array}$ \\
\hline $\mathrm{C}_{12} \mathrm{MIM} \mathrm{BF}_{4}$ & & & & & & & $\begin{array}{c}6870 \pm 280 \\
51 \pm 12\end{array}$ \\
\hline \multicolumn{8}{|l|}{$\beta-C D$} \\
\hline $\mathrm{EMIM} \mathrm{NTf}_{2}$ & 0 & 0 & 0 & 0 & 0 & 0 & \\
\hline $\mathrm{BMIM} \mathrm{BF}_{4}$ & 0 & 0 & 0 & 0 & 0 & 0 & \\
\hline BMIM NTf 2 & 0 & 0 & 0 & 0 & 0 & 0 & \\
\hline $\mathrm{BMMIM} \mathrm{BF}_{4}$ & 0 & 0 & 0 & 0 & 0 & 0 & \\
\hline $\mathrm{C}_{8} \mathrm{MIM} \mathrm{Br}$ & 643 & 680 & 657 & 712 & 639 & $672 \pm 50$ & \\
\hline $\mathrm{C}_{10} \mathrm{MIM} \mathrm{BF}_{4}$ & 2914 & 3211 & 3372 & 2223 & 3346 & $3038 \pm 290$ & \\
\hline $\mathrm{C}_{12} \mathrm{MIM} \mathrm{BF}_{4}$ & 9910 & 10891 & 10026 & 13029 & 10028 & $10994 \pm 600$ & \\
\hline \multicolumn{8}{|l|}{$\gamma-\mathrm{CD}$} \\
\hline EMIM NTf 2 & 0 & 0 & 0 & 0 & 0 & 0 & \\
\hline $\mathrm{BMIM} \mathrm{BF}_{4}$ & 0 & 0 & 0 & 0 & 0 & 0 & \\
\hline BMIM NTf 2 & 0 & 0 & 0 & 0 & 0 & 0 & \\
\hline $\mathrm{BMMIM} \mathrm{BF}_{4}$ & 0 & 0 & 0 & 0 & 0 & 0 & \\
\hline $\mathrm{C}_{8} \mathrm{MIM} \mathrm{Br}$ & 0 & 0 & 0 & 0 & 0 & 0 & \\
\hline $\mathrm{C}_{10} \mathrm{MIM} \mathrm{BF}_{4}$ & 107 & 105 & 107 & 104 & 106 & $106 \pm 3$ & \\
\hline $\mathrm{C}_{12} \mathrm{MIM} \mathrm{BF}_{4}$ & 250 & 230 & 255 & 230 & 260 & $244 \pm 20$ & \\
\hline \multicolumn{8}{|l|}{$\mathrm{HP}-\alpha-\mathrm{CD}$} \\
\hline EMIM NTf 2 & 0 & 0 & 0 & 0 & 0 & 0 & \\
\hline $\mathrm{BMIM} \mathrm{BF}_{4}$ & 13 & 15 & 11 & 11 & 10 & $12 \pm 2$ & \\
\hline BMIM NTf 2 & 12 & 15 & 10 & 10 & 9 & $11 \pm 2$ & \\
\hline $\mathrm{BMMIM} \mathrm{BF}_{4}$ & 15 & 20 & 12 & 13 & 10 & $14 \pm 2$ & \\
\hline $\mathrm{C}_{8} \mathrm{MIM} \mathrm{Br}$ & 527 & 630 & 644 & 660 & 633 & $642 \pm 50$ & \\
\hline $\mathrm{C}_{10} \mathrm{MIM} \mathrm{BF}_{4}$ & 2062 & 2802 & 2334 & 2904 & 2310 & $2588 \pm 200$ & \\
\hline $\mathrm{C}_{12} \mathrm{MIM} \mathrm{BF}_{4}$ & 4467 & 4846 & 5552 & 4657 & 5563 & $5155 \pm 350$ & \\
\hline \multicolumn{8}{|l|}{$\mathrm{HP}-\beta-\mathrm{CD}$} \\
\hline EMIM NTf 2 & $\overline{0}$ & 0 & $\overline{0}$ & $\overline{0}$ & $\overline{0}$ & $\overline{0}$ & \\
\hline $\mathrm{BMIM} \mathrm{BF}_{4}$ & 0 & 0 & 0 & 0 & 0 & 0 & \\
\hline $\mathrm{BMIM} \mathrm{NTf}_{2}$ & 0 & 0 & 0 & 0 & 0 & 0 & \\
\hline $\mathrm{BMMIM} \mathrm{BF}_{4}$ & 0 & 0 & 0 & 0 & 0 & 0 & \\
\hline $\mathrm{C}_{8} \mathrm{MIM} \mathrm{Br}$ & 225 & 256 & 260 & 269 & 255 & $260 \pm 20$ & \\
\hline $\mathrm{C}_{10} \mathrm{MIM} \mathrm{BF}_{4}$ & 1190 & 1322 & 1389 & 1430 & 1367 & $1377 \pm 90$ & \\
\hline $\mathrm{C}_{12} \mathrm{MIM} \mathrm{BF}_{4}$ & 4321 & 5228 & 5558 & 4350 & 5647 & $5196 \pm 550$ & \\
\hline \multicolumn{8}{|l|}{$\mathrm{HP}-\gamma-\mathrm{CD}$} \\
\hline EMIM NTf 2 & 0 & 0 & 0 & 0 & 0 & 0 & \\
\hline $\mathrm{BMIM} \mathrm{BF}_{4}$ & 0 & 0 & 0 & 0 & 0 & 0 & \\
\hline BMIM NTf 2 & 0 & 0 & 0 & 0 & 0 & 0 & \\
\hline $\mathrm{BMMIM} \mathrm{BF}_{4}$ & 0 & 0 & 0 & 0 & 0 & 0 & \\
\hline $\mathrm{C}_{8} \mathrm{MIM} \mathrm{Br}$ & 14 & 20 & 14 & 14 & 14 & $16 \pm 3$ & \\
\hline $\mathrm{C}_{10} \mathrm{MIM} \mathrm{BF}_{4}$ & 60 & 70 & 65 & 75 & 63 & $68 \pm 6$ & \\
\hline $\mathrm{C}_{12} \mathrm{MIM} \mathrm{BF}_{4}$ & 230 & 225 & 235 & 241 & 240 & $235 \pm 20$ & \\
\hline \multicolumn{8}{|l|}{ DM- $\beta-C D$} \\
\hline EMIM NTf 2 & 0 & 0 & 0 & 0 & 0 & 0 & \\
\hline $\mathrm{BMIM} \mathrm{BF}_{4}$ & 0 & 0 & 0 & 0 & 0 & 0 & \\
\hline $\mathrm{BMIM} \mathrm{NTf}_{2}$ & 0 & 0 & 0 & 0 & 0 & 0 & \\
\hline $\mathrm{BMMIM} \mathrm{BF}_{4}$ & 0 & 0 & 0 & 0 & 0 & 0 & \\
\hline $\mathrm{C}_{8} \mathrm{MIM} \mathrm{Br}$ & 717 & 720 & 710 & 660 & 690 & $695 \pm 70$ & \\
\hline $\mathrm{C}_{10} \mathrm{MIM} \mathrm{BF}_{4}$ & & & & & & & $\begin{array}{c}2620 \pm 290 \\
17 \pm 6\end{array}$ \\
\hline $\mathrm{C}_{12} \mathrm{MIM} \mathrm{BF}_{4}$ & & & & & & & $8685 \pm 1050$ \\
\hline & & & & & & & $11 \pm 3$ \\
\hline \multicolumn{8}{|l|}{ TM- $\beta-C D$} \\
\hline EMIM NTf 2 & 0 & 0 & 0 & 0 & 0 & 0 & \\
\hline $\mathrm{BMIM} \mathrm{BF}_{4}$ & 0 & 0 & 0 & 0 & 0 & 0 & \\
\hline $\mathrm{BMIM} \mathrm{NTf}_{2}$ & 0 & 0 & 0 & 0 & 0 & 0 & \\
\hline $\mathrm{BMMIM} \mathrm{BF}_{4}$ & 0 & 0 & 0 & 0 & 0 & 0 & \\
\hline $\mathrm{C}_{8} \mathrm{MIM} \mathrm{Br}$ & 70 & 75 & 67 & 67 & 64 & $68 \pm 4$ & \\
\hline $\mathrm{C}_{10} \mathrm{MIM} \mathrm{BF}_{4}$ & 280 & 245 & 260 & 280 & 250 & $259 \pm 20$ & \\
\hline $\mathrm{C}_{12} \mathrm{MIM} \mathrm{BF}_{4}$ & 892 & 789 & 872 & 794 & 855 & $828 \pm 80$ & \\
\hline
\end{tabular}

* $\sigma$ : standard deviations as calculated from $\mathrm{x}$-reciprocal treatment $(\mathrm{n}=10$ for a given IL) 
Table 4

Main physical properties of native cyclodextrins [44]

\begin{tabular}{lccc}
\hline & $\alpha$ & $\beta$ & $\gamma$ \\
\hline Number of glucose units & 6 & 7 & 8 \\
Molecular mass & 972.8 & 1135.0 & 1297.1 \\
Inner diameter of the cavity $(\AA)$ & $4.7-5.3$ & $6.0-6.5$ & $7.5-8.3$ \\
Diameter of outer periphery $(\AA)$ & $14.6 \pm 0.4$ & $15.4 \pm 0.4$ & $17.5 \pm 0.4$ \\
Height of torus $(\AA)$ & $7.9 \pm 0.1$ & $7.9 \pm 0.1$ & $7.9 \pm 0.1$ \\
Approx volume of cavity $\left(\AA^{3}\right)$ & 174 & 262 & 427 \\
\hline
\end{tabular}




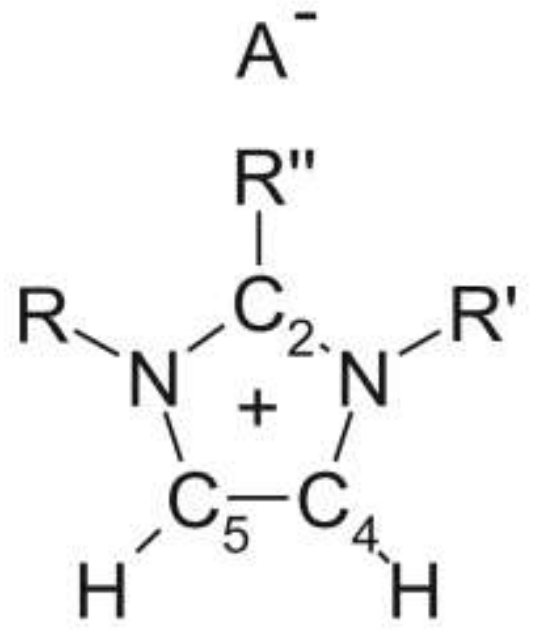

Figure 1: Ionic liquids studied in this work.

1-ethyl-3-methylimidazolium bis(trifluoromethanesulfonyl)imide $\left(\mathrm{R}=\mathrm{Et}, \mathrm{R}\right.$ ' = Me, R' = H, A = $\left.\mathrm{NTf}_{2}\right)$

1-butyl-3-methylimidazolium bis(trifluoromethanesulfonyl)imide $\left(\mathrm{R}=\mathrm{Bu}, \mathrm{R}^{\prime}=\mathrm{Me}, \mathrm{R}{ }^{\prime}=\mathrm{H}, \mathrm{A}=\mathrm{NTf}_{2}\right)$

1-butyl-3-methylimidazolium tetrafluoroborate

$\left(\mathrm{R}=\mathrm{Bu}, \mathrm{R}^{\prime}=\mathrm{Me}, \mathrm{R}{ }^{\prime}=\mathrm{H}, \mathrm{A}=\mathrm{BF}_{4}\right)$

1-butyl-2,3-dimethylimidazolium tetrafluoroborate

$\left(\mathrm{R}=\mathrm{Bu}, \mathrm{R}^{\prime}=\mathrm{Me}, \mathrm{R}^{\prime}{ }^{\prime}=\mathrm{Me}, \mathrm{A}=\mathrm{BF}_{4}\right)$

1-octyl-3-methylimidazolium bromide

$\left(\mathrm{R}=\mathrm{C}_{8}, \mathrm{R}^{\prime}=\mathrm{Me}, \mathrm{R}{ }^{\prime}=\mathrm{H}, \mathrm{A}=\mathrm{Br}\right)$

1-decyl-3-methylimidazolium tetrafluoroborate

$\left(\mathrm{R}=\mathrm{C}_{10}, \mathrm{R}^{\prime}=\mathrm{Me}, \mathrm{R}{ }^{\prime}=\mathrm{H}, \mathrm{A}=\mathrm{BF}_{4}\right)$

1-dodecyl-3-methylimidazolium tetrafluoroborate

$\left(\mathrm{R}=\mathrm{C}_{12}, \mathrm{R}^{\prime}=\mathrm{Me}, \mathrm{R}{ }^{\prime}{ }^{\prime}=\mathrm{H}, \mathrm{A}=\mathrm{BF}_{4}\right)$ 


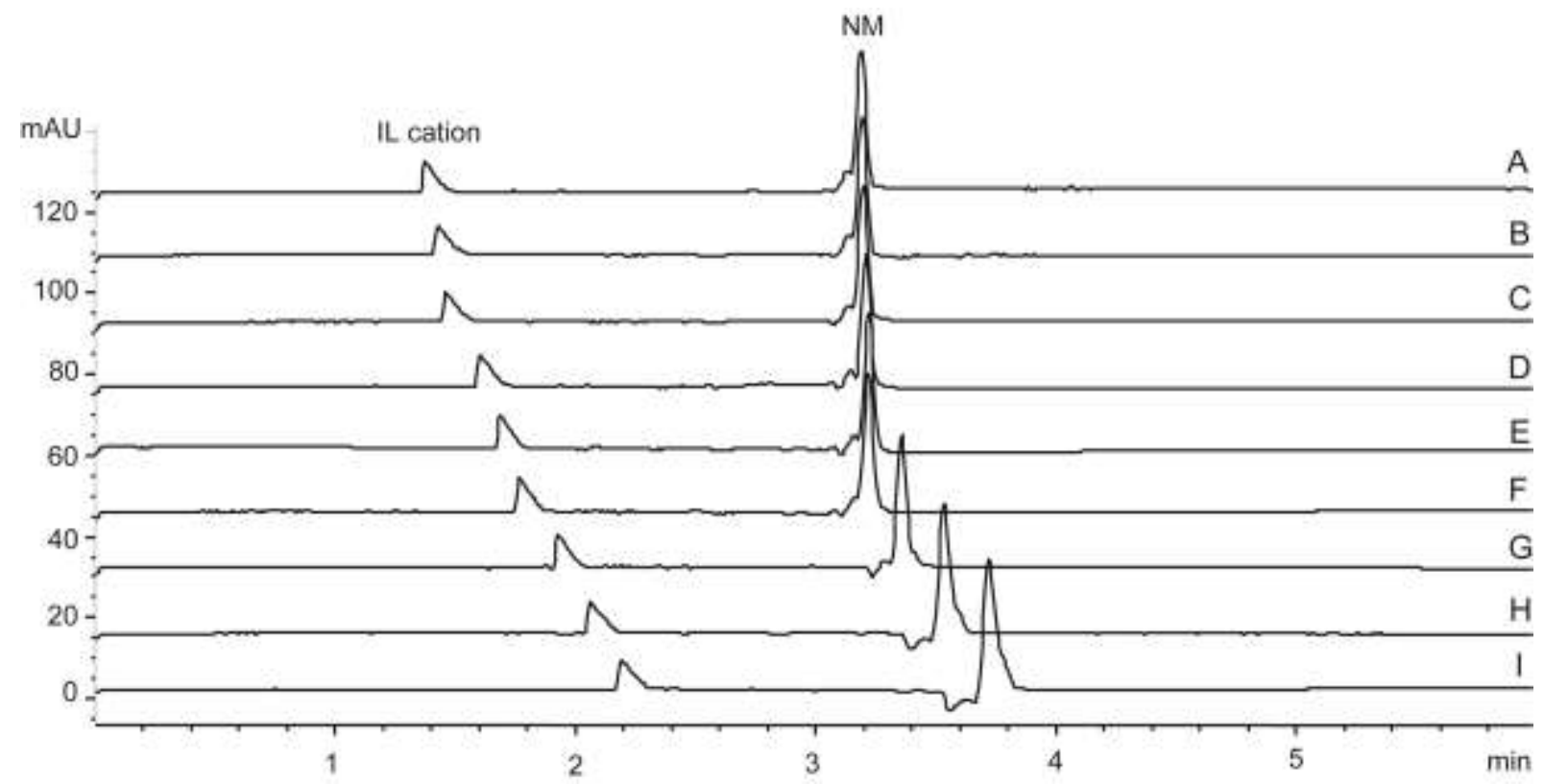

Figure 2: Electropherograms showing the mobility shift of 1-octyl-3-methylimidazolium cation $\left(\mathrm{C}_{8} \mathrm{MIM}\right)$ as a function of $\alpha-\mathrm{CD}$ concentration in the running buffer. A : Zero (neat background buffer) ; B : $1 \mathrm{mM}$; C : $2 \mathrm{mM}$; D : $3 \mathrm{mM}$; E : $5 \mathrm{mM} ; \mathrm{F}: 10 \mathrm{mM}$; G : $20 \mathrm{mM}$; $\mathrm{H}: 30 \mathrm{mM} ; \mathrm{I}: 50 \mathrm{mM}$.

Experimental conditions: bare fused silica capillary, $50 \mu \mathrm{m}$ i.d. x $35 \mathrm{~cm}$ (detection cell, 26.5 $\mathrm{cm}$ ). Running electrolyte: $30 \mathrm{mM}$ sodium acetate buffer, $\mathrm{pH} 5.0$ (ionic strength, $30 \mathrm{mM}$ ) containing $\alpha-C D$ at various concentrations (A to G). Applied voltage: $20 \mathrm{kV}$ (current intensity: $50 \mu \mathrm{A}$ ). Temperature: $25^{\circ} \mathrm{C}$. Injection protocol: see Experimental. Sample: $2 \mathrm{mM}$ $\mathrm{C}_{8} \mathrm{MIM} \mathrm{Br}$ in the sodium acetate buffer, $\mathrm{pH}$ 5.0. NM: neutral marker. 


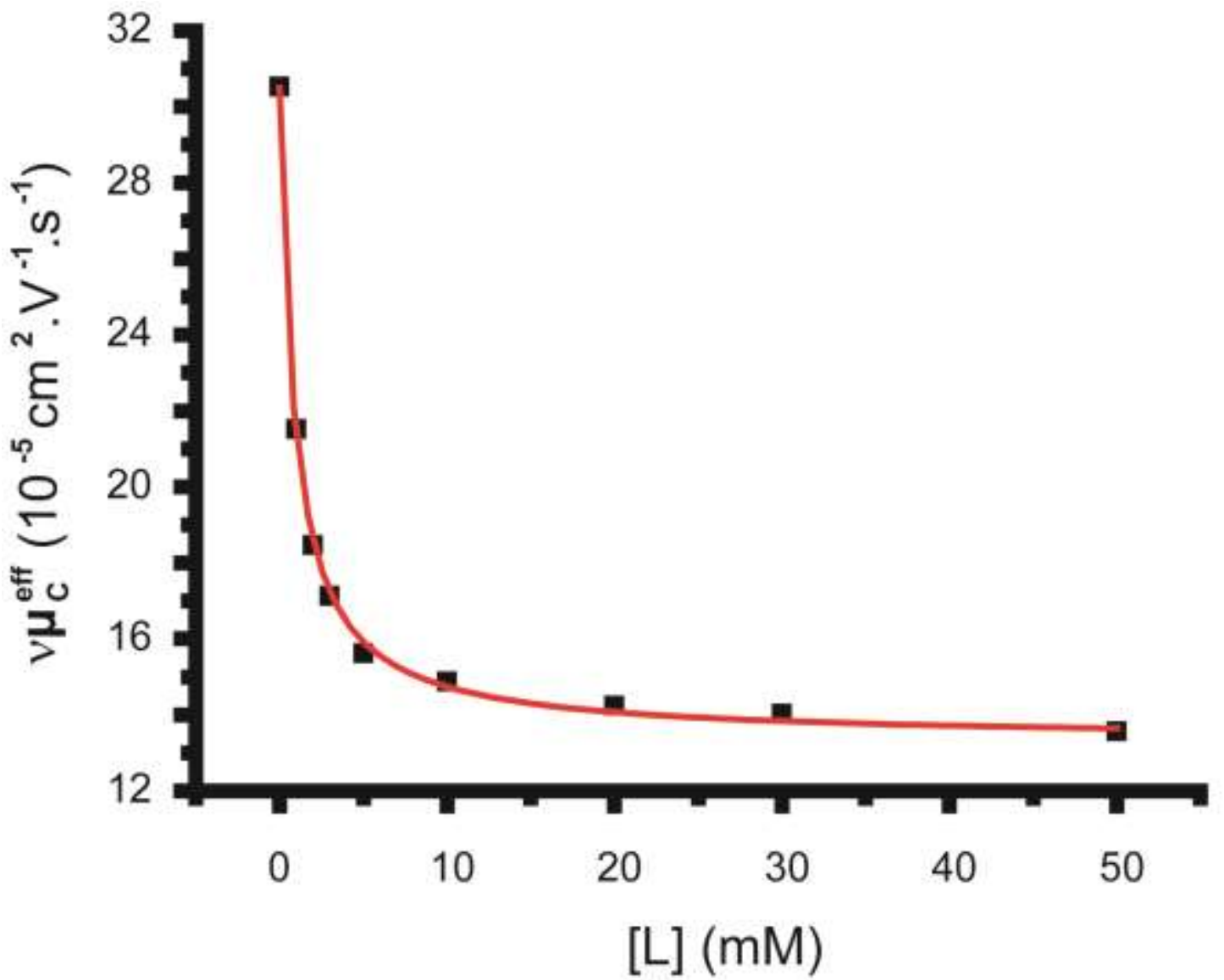

Figure 3: Variation of the effective mobility $\mu_{\mathrm{C}} \mathrm{eff}^{\mathrm{ff}}$ (corrected for viscosity variations) of 1octyl-3-methylimidazolium cation $\left(\mathrm{C}_{8} \mathrm{MIM}\right)$ as a function of the $\alpha-\mathrm{CD}$ concentration in the running electrolyte (binding isotherm plot). The solid line represents the non-linear leastsquares fitting of the data to Eq. 4. Experimental conditions, see Fig. 2. 

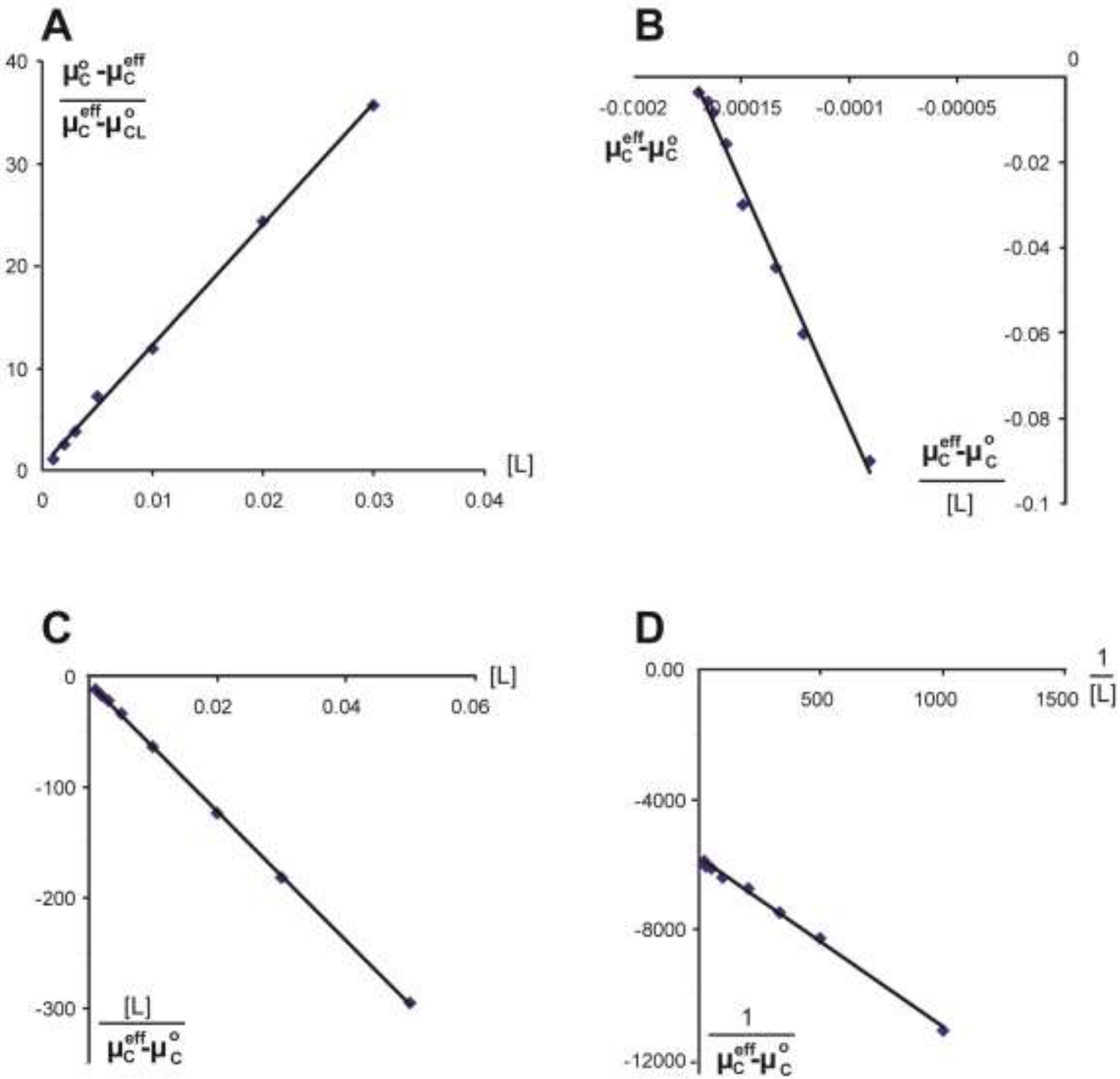

Figure 4: Linearized representations of the 1:1 binding isotherm for 1-octyl-3methylimidazolium cation $\left(\mathrm{C}_{8} \mathrm{MIM}\right)$, in the presence of variable concentrations of $\alpha-\mathrm{CD}$ : directly linearized isotherm (A), x-reciprocal (B), y-reciprocal (C), and double reciprocal (D) forms (see Table 1 for equations). Experimental conditions, see Fig. 2. Concentrations of ligand $\mathrm{L}(\alpha-\mathrm{CD})$ in $\mathrm{M}$ and effective mobilities in $10^{-5} \mathrm{~cm}^{2} \cdot \mathrm{V}^{-1} \cdot \mathrm{s}^{-1}$.

Equations of the least-squares regression straight lines:
$A: y=1184.9 x+0.3542, R^{2}=0.999$
$\mathrm{B}: \mathrm{y}=-1133.2 \mathrm{x}-0.1948, \mathrm{R}^{2}=0.994$
$\mathrm{C}: \mathrm{y}=-5820.1 \mathrm{x}-5.3491, \mathrm{R}^{2}=0.999$
$D: y=-5.2051 x-5801.2, R^{2}=0.997$ 


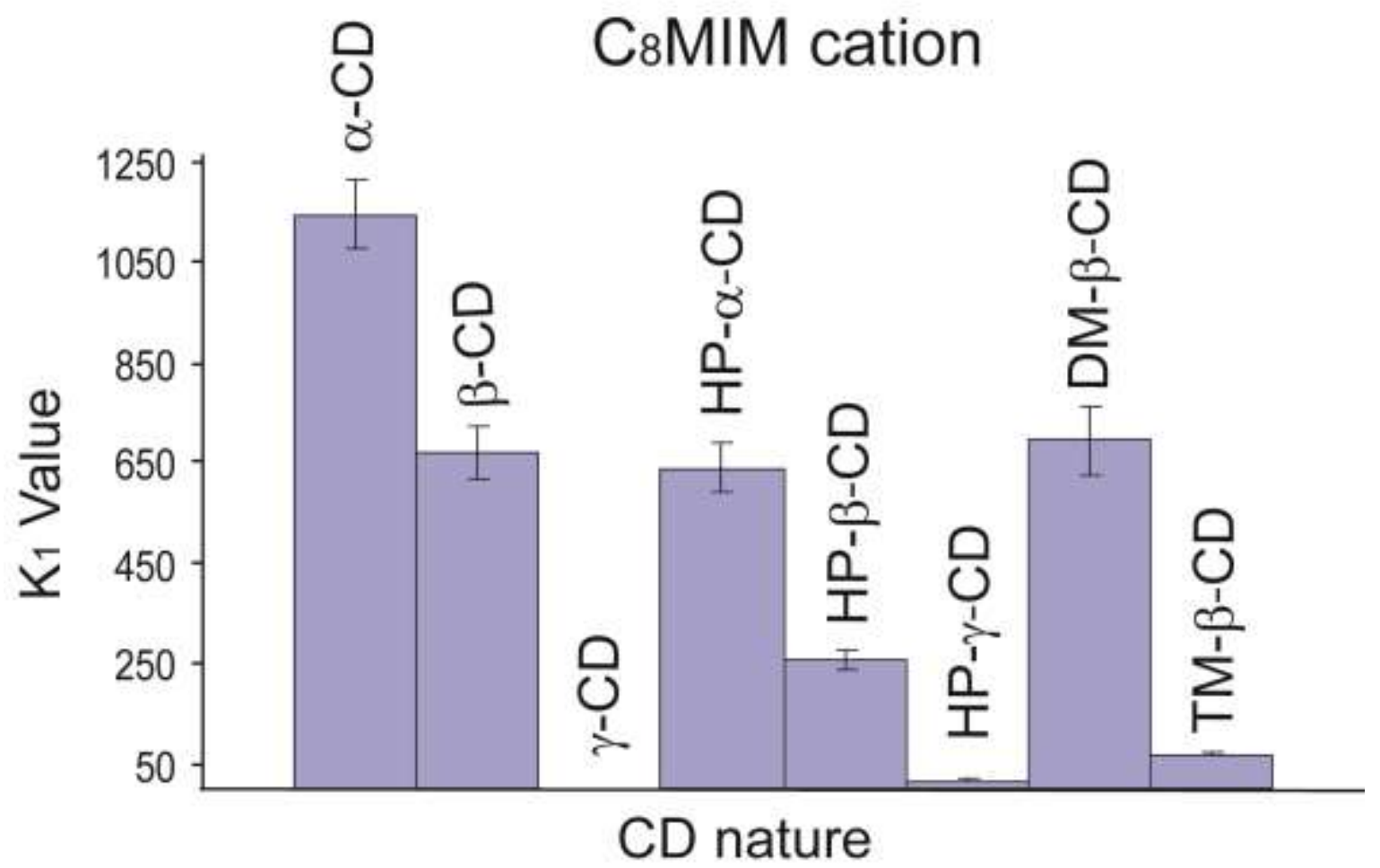

Figure 5 : Histogram representing the $\mathrm{K}_{1}$ value for 1-octyl-3-methylimidazolium cation $\left(\mathrm{C}_{8} \mathrm{MIM}\right)$ as a function of the $\mathrm{CD}$ nature, bars represent standard deviation. Experimental conditions, see Fig. 2. 

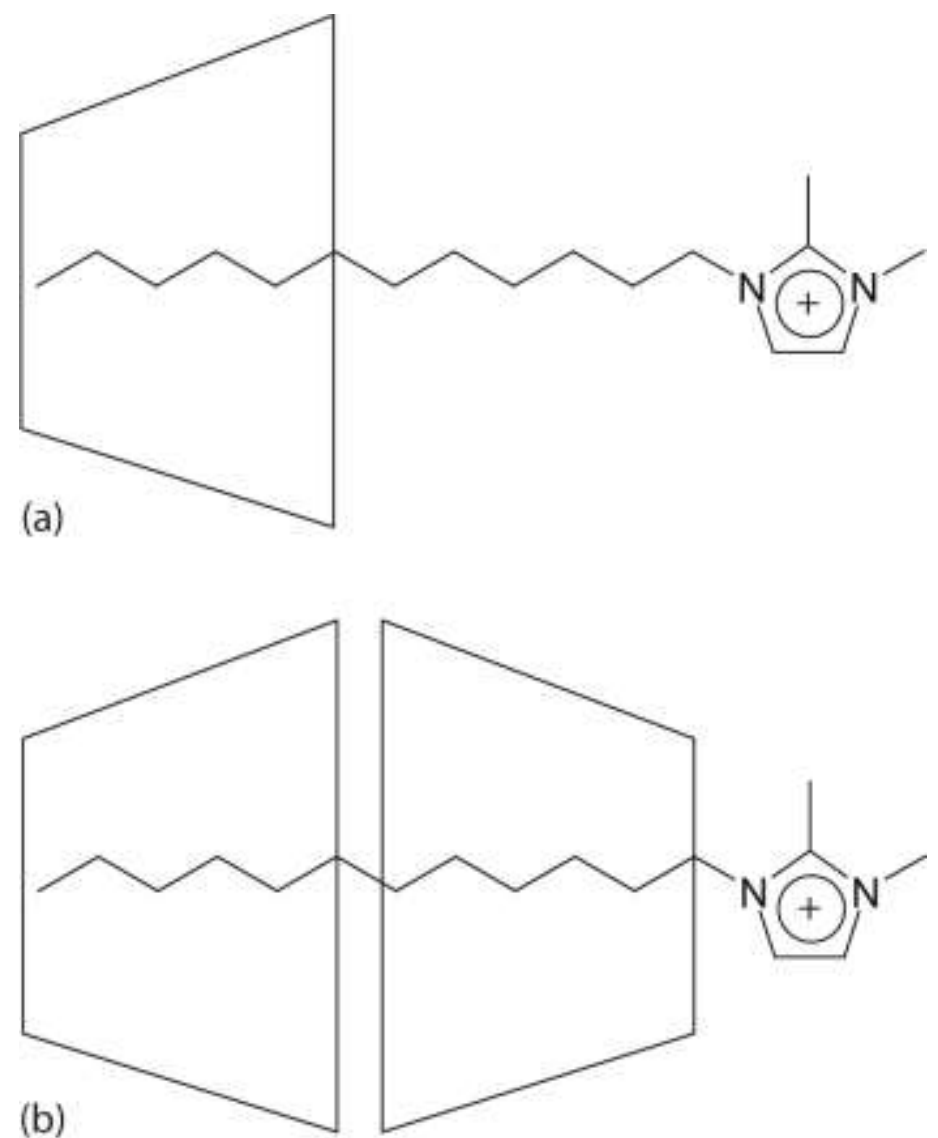

Figure 6: Schematic representation of (a) the 1:1 and (b) 1:2 complexes between alkyl(methyl)methylimidazolium cation and CDs, as inferred from ref. [55] 